\begin{tabular}{|c|c|} 
Available online at: http://ejournal-balitbang.kkp.go.id/index.php/ifrj & e-mail:ifrj.puslitbangkan@gmail.com \\
INDONESIAN FISHERIES RESEARCH JOURNAL & Volume 25 Nomor 2 December 2019 \\
p-ISSN: 0853-8980 & e-ISSN: 2502-6569 \\
Accreditation Number RISTEKDIKTI: 21/E/KPT/2018
\end{tabular}

\title{
ESTIMATION OF GROWTH, MORTALITY, AND EXPLOITATION STATUS OF NURSE TETRA (Brycinus nurse) AND TRUE BIG SCALE TETRA (Brycinus macrolepidotus) (FAMILY: ALESTIDAE) FROM THE NEW CALABAR RIVER, NIGERIA
}

\author{
Olaniyi Alaba Olopade ${ }^{\star 1}$, Henry Eyina Dienye ${ }^{1}$ and Uzoma C Nworgu ${ }^{1}$ \\ ${ }^{1}$ Department of Fisheries, Faculty of Agriculture, University of Port Harcourt, Nigeria \\ Received; April 20-2019 Received in revised from December 02-2018; Accepted December 11-2019
}

\begin{abstract}
This study aimed to determine the growth patterns, mortality, and exploitation status of two species of Alestidae in the New Calabar River, Nigeria. For this purpose, fish samples were collected monthly from three landing sites from the local fishermen using gill nets (mesh sizes: 15-25mm), beach seine (mesh sizes: $2.3-10 \mathrm{~mm}$ ), and cast nets (mesh sizes: $15-25 \mathrm{~mm}$ ). The length-weight relationship revealed exponent "b" value for Brycinus nurse was 3.54 and 3.21 for Brycinus macrolepidotus while the condition factors were 1.08 and 1.02 for Brycinus nurse and Brycinus macrolepidotus respectively. The growth parameters of Brycinus nurse asymptotic length $\left(\mathrm{L}_{\infty}\right)$ and growth coefficient $(\mathrm{K})$ were $24.46 \mathrm{~cm}$ and $0.52 \mathrm{yr}^{-1}$, respectively, while those for Brycinus macrolepidotus $L_{\infty}$ was $28.88 \mathrm{~cm}$ and $K$ was $0.22 \mathrm{yr}^{-1}$. The reproductive load $\left(L_{50} / L_{\infty}\right)$ ratio was found to be 0.59 and 0.61 for $B$. nurse and $B$. macrolepidotus, respectively. Exploitation rate (E) for $B$. nurse was 0.26 and 0.11 for $B$. macrolepidotus while length-at-first capture $\left(L_{c}\right)$ was $14.49 \mathrm{~cm}$ for $B$. nurse and $17.64 \mathrm{~cm}$ for $B$. macrolepidotus. The natural mortality was greater than the fishing mortality for both species and Logistic regression of the probability of capture routine values recorded for $B$. nurse were higher than that of $B$. macrolepidotus. Maximum exploitation rate $\left(E_{\max }\right)$ was less than 0.5 for both $B$. nurse $(0.41)$ and $B$. macrolepidotus $(0.42)$. These values were close to the maximum allowable limit; therefore, the species may be unsustainable when fishery intensifies in the future. To ensure sustainable exploitation of the two Alestid species in the area, fishing effort should be regulated.
\end{abstract}

Keywords: Alestid species; length-weigth relationship; reproductive load; demographic structure; Nigeria

\section{INTRODUCTION}

Alestidae has been described as the most speciose of all African characiform families (Paugy \& Schaefer, 2007; Arroyave \& Stiassny, 2011). About 118 valid species from family Alestidae greatly vary in body and fin sizes, shapes, and occupied ecological niches (Froese \& Pauly, 2016). According to Froese \& Pauly (2017), about 21 species spread across eight genera (Alestes, Alestopetersius, Anorldichthys, Brycinus, Hydrocinus, Bryconaethiops, Micralestes, and Rhabdalestes) have been found in Nigerian waters. Off the eight genera, the genus Brycinus is the most prevalent in Nigerian freshwaters with ten species. The genus Brycinus is characterized by presence of rudimentary adipose eyelids, and by having two rows of pluricuspid teeth on the upper jaw (Paugy, 2003). The exploitation history of Characidae from Nigerian waters, according to the NBS (2015), revealed that the annual catch of the characid species from 2010 to 2015 ranged between 14,784 to 23,124 metric tons $(\mathrm{mt})$, where $23,124 \mathrm{mt}$ was the highest landing occurred in 2014 then decreased to 18,356 mt in 2015.

Brycinus macrolepidotus (Valenciennes, 1850) and Brycinus nurse (Rüppell, 1832) are native to freshwater systems in Africa thriving well in both lacustrine and riverine conditions (Boulenger, 2002), particularly in the Niger Delta, Nigeria. Brycinus macrolepidotus is easily identified by red marks on pectoral, ventral, and anal fins, the tip of adipose fins is reddish, the tail fin of $B$. nurse is bright red, other fins are tinged with red, and there is black patch on the tail peduncle (Adesulu \& Sydenham, 2007). These species are said to be of commercial importance due to the fact that they are widely consumed locally and have food value (Reed et al., 1967; Saliu \& Fagade, 2004). Like other commercially important fish species in Nigerian inland 
waters, this fish family is currently subjected to intense fishing pressure due to lack of proper management policy. Since unregulated exploitation is still on there are urgent needs to monitor and assess the status of the stocks that are being fished.

Fish stock change depends on recruitment, natural mortality, individual growth, and harvesting. The growth parameters and the mortality rate are important tools to assess the exploitation level of the pelagic species (Wang \& Liu, 2006). Length and weight data of fish can be used for the estimation of the length and age structures growth and mortality rates of the fish (Kohler et al., 1995) and the condition factor that may help determine whether somatic growth is isometric or allometric (Ricker, 1975). Relationship between length and weight is required for setting up yield equation (Beverton \& Hold 1957; Ricker 1968).

The biological information on fish is of paramount importance for the development of effective strategies for their management and conservation. Information on population parameters, i.e., growth, reproduction, recruitment, as well as mortality of fish, is vital to the implementation of sustainable management strategies for their better conservation (Hossain et al., 2009). The present study was thus undertaken to estimate the key biological information on two most dominant Alestid species caught in the New Calabar River, Nigeria.

\section{MATERIALS AND METHODS}

The Niger Delta is crossed by many distributaries. Off these distributaries is the New Calabar River in the Niger River Delta, Nigeria. It is a partially mixed estuary river lies between latitude 40252 $\mathrm{N}$ and longitude $7^{\circ} 162 \mathrm{E}$ (Olopade et al., 2018). It runs through the most densely populated areas in the hinterland and empties into the Atlantic Ocean at the southern tip of Bonny in the south. The river has high water volume during rainy season due to high runoff. The main rainy season is from April to September with the annual rainfall between 2000 and $3000 \mathrm{~mm}$ (Abowei \& Hart, 2009). Rainfall is generally negligible in December and February.

Three non-overlapping landing sites were selected along the New Calabar River, namely Choba, Aluu, and Ogbogoro (Figure 1) to provide a representative overview of the fisheries in the river. The fish samples were also collected monthly from three landing sites from the local fishermen using gill nets (mesh sizes: 15-25 mm), beach seine (mesh sizes: $2.3-10 \mathrm{~mm}$ ), and cast nets (mesh sizes: $15-25 \mathrm{~mm}$ ). The fish species were identified using fish identification keys (Paugy, 2003; Adesulu \& Sydenham, 2007). Total length, standard length, and weight of the fish species were measured in centimeters and grams, respectively.

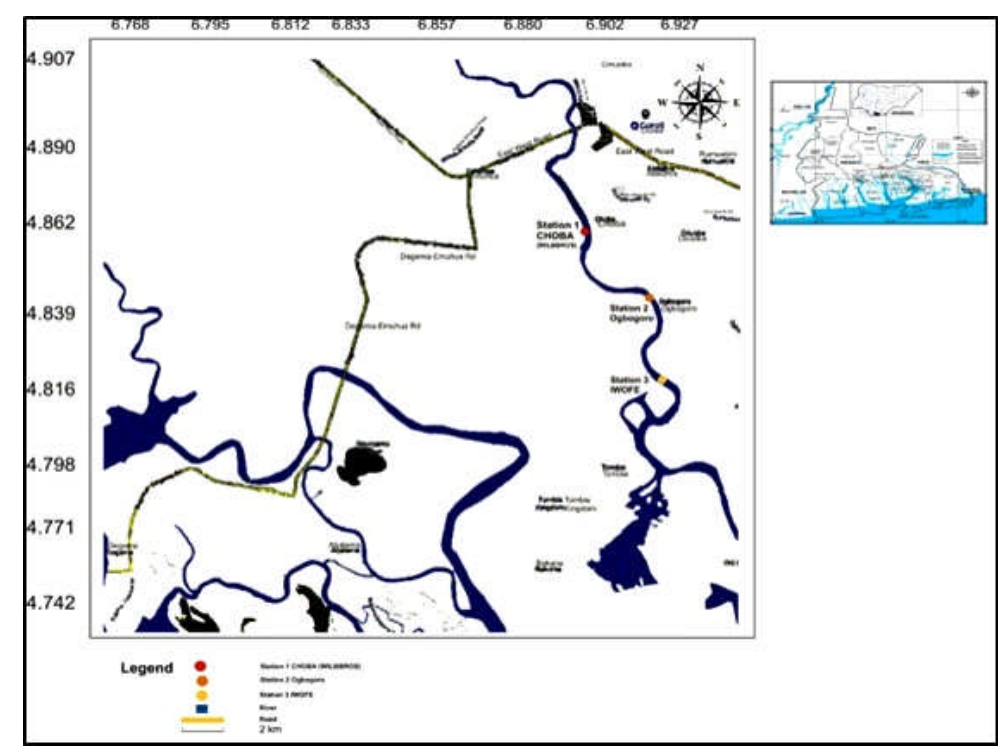

Figure 1. Map Showing New Calabar River, Rivers State Nigeria.

\section{Data Analysis}

The length-weight relationship is expressed by the equation $\mathrm{W}=a L^{b}$, where $\mathrm{W}=$ Body weight $(\mathrm{g})$, and $L=$ Total length $(\mathrm{cm})$, Ricker (1973) as follows:

$\log W=a+b \log L$
The value of the growth exponent was used to calculate the condition factor using the formula:

$\mathrm{K}=100 \mathrm{~W} / \mathrm{L}^{\mathrm{b}}$

Where;

$\mathrm{K}=$ condition factor 


$$
\begin{aligned}
& \mathrm{W}=\text { total body weight }(\mathrm{g}) \\
& \mathrm{L}=\text { Total length }(\mathrm{cm}) \text { and } \\
& \mathrm{b}=\text { growth exponent }
\end{aligned}
$$

The length-frequency data for each species were collected monthly from the different sampling sites and subsequently grouped into class intervals for analysis. The data was analyzed using FiSAT II (FAOICLARM Stock Assessment Tools) as explained in detail by (Gayanilo et al., 2005).

The von Bertalanffy growth parameters (Pauly, 1980), $L_{\infty}$ and annual growth coefficient $K$ were computed by ELEFAN I (Electronic Length Frequency Analysis) (Beverton \& Holt, 1966). The total mortality rate $(Z)$ was estimated by length-converted catch curve (Pauly, 1984). The natural mortality rate $(M)$ was also calculated by using Pauly's empirical formula (Pauly, 1980). The fishing mortality rate $(F)$ was calculated by the difference between $(Z)$ and $(M)$ or

$$
\mathrm{F}=\mathrm{Z}-\mathrm{M}
$$

The rate of exploitation (E) was calculated by the quotient between fishing and total mortality (Pauly, 1984):
$E=F / Z$

Relative yield per recruit $(Y / R)$ was estimated using the model of Beverton \& Holt (Beverton \& Holt, 1966) as modified by Pauly \& Soriano (1986) and incorporated in the FiSAT software.

Resource status was evaluated by comparing estimates of the fishing mortality rate with a target $\left(\mathrm{F}_{\text {opt }}\right)$ and limit $\left(\mathrm{F}_{\text {limit }}\right)$ biological reference points (BRP) which were defined as $F_{\text {opt }}=0.5 \mathrm{M}$ and $F_{\text {limit }}=2 / 3 \mathrm{M}$ (Patterson, 1992).

Probability of capture against mid-length a resultant curve was used to compute the length at first capture (Lc50). The length at first maturity (Lm50) was estimated as $\operatorname{Lm50}=\left(2{ }^{*} \mathrm{~L}_{\infty}\right) / 3$ (Hoggarth et al., 2006)

\section{RESULTS AND DISCUSSION Results}

A total of 196 individuals Alestid species belong to two species, namely B. macrolepidotus and B. nurse, were analyzed during this study. Brycinus nurse occurred in considerable number $(64.3 \%)$ more than B. macrolepidotus with $35.7 \%$ (Table 1 ).

Table 1. Species composition by number from all types of gears

\begin{tabular}{lccccc}
\hline Species & Beach seine & Cast net & Gillnet & N & Percentage (\%) \\
\hline B. macrolepidotus & 29 & 23 & 18 & 70 & 35.7 \\
B.nurse & 53 & 27 & 46 & 126 & 64.3 \\
Total & 82 & 50 & 64 & 196 & 100
\end{tabular}

The mean total lengths were estimated to be $15.08 \pm 0.37$ and $14.58 \pm 0.25 \mathrm{~cm}$ for $B$. macrolepidotus and $B$. nurse, respectively. The mean weight for $B$. macrolepidotus was estimated as $40.00 \pm 3.57 \mathrm{~g}$, whereas it was $39.44 \pm 2.73 \mathrm{~g}$ for $B$. nurse (Table 2 ). The length-weight relationship results revealed exponent of (b) values of 3.2103 and 3.5405 for $B$. macrolepidotus and $B$. nurse, respectively (Table 2 , Fig. 2 and 3). Also the correlation value (r) for the two species were estimated as 0.8868 and 0.8853 , respectively. The mean value for condition factor $(\mathrm{K})$ recorded for $B$. macrolepidotus was $1.02 \pm 0.03$, and

\begin{tabular}{|c|c|c|c|c|c|c|c|c|}
\hline \multirow[t]{2}{*}{ Species } & \multicolumn{2}{|l|}{ TL (cm) } & \multicolumn{2}{|l|}{ SL(cm) } & \multicolumn{2}{|l|}{ WEIGHT (g) } & \multicolumn{2}{|l|}{ GIRTH (cm) } \\
\hline & Mean \pm SE & Range & $\begin{array}{c}\text { Mean } \pm \\
\text { SE }\end{array}$ & Range & $\begin{array}{l}\text { Mean } \pm \\
\text { SE }\end{array}$ & Range & $\begin{array}{l}\text { Mean } \pm \\
\text { SE }\end{array}$ & \\
\hline B. macrolepidotus & $5.08 \pm 0.37$ & $11.50-27.00$ & $11.88 \pm 0.30$ & $8.70-22.30$ & $40.00 \pm 3.57$ & $10.00-160.00$ & $8.80 \pm 0.25$ & $6.00-15.30$ \\
\hline Brycinus nurse & $14.58 \pm 0.25$ & $7.30-23.00$ & $11.49 \pm 0.20$ & $5.50-18.60$ & $39.44 \pm 2.73$ & $5.00-210.00$ & $8.80 \pm 0.19$ & $2.50-16.50$ \\
\hline
\end{tabular}
$B$. nurse had the value of $1.08 \pm 0.02$ (Table 3 ).

Table 2. Total length, standard length and Mean weight of Alestid species from New Calabar River landed by all type of fishing gears 


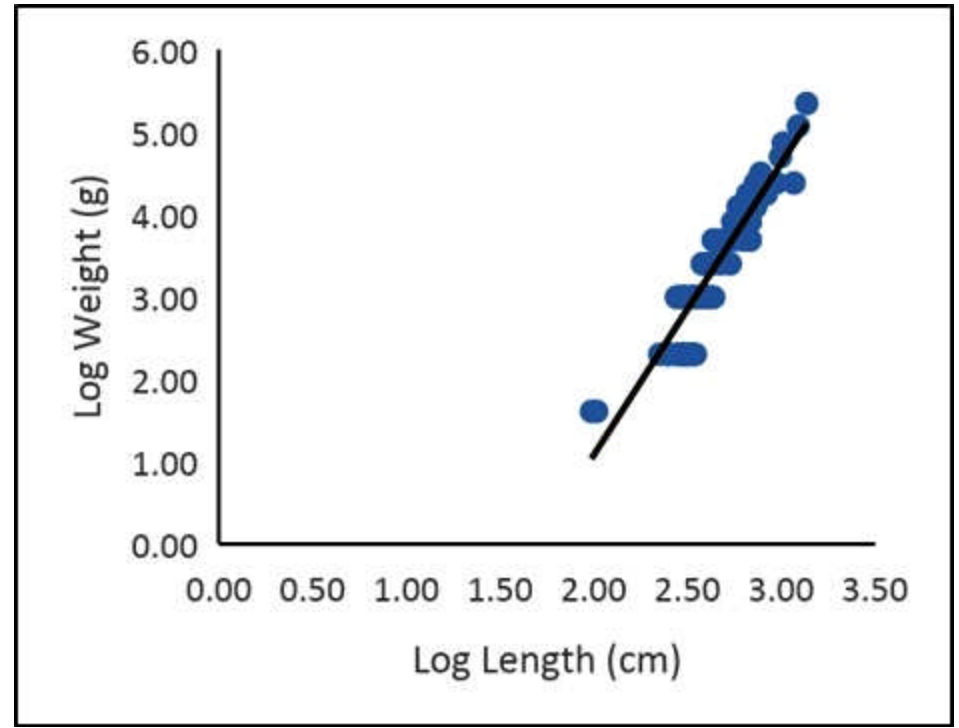

Figure 2. Length-weight relationship of B. macrolepidotus in the New Calabar River.

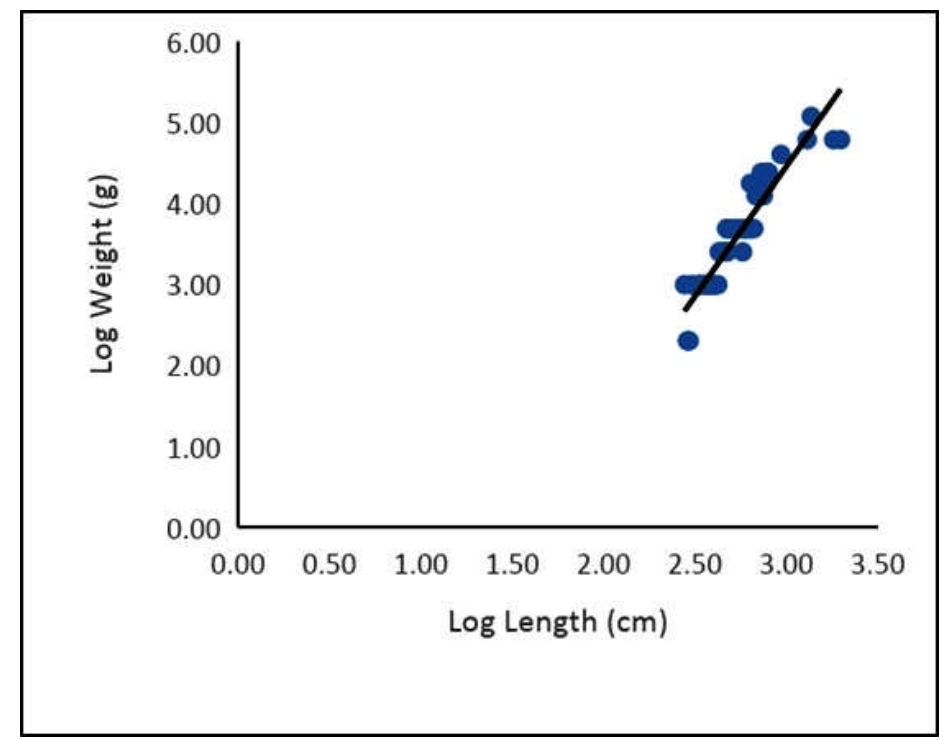

Figure 3. Length-weight relationship of $B$. nurse in the New Calabar River.

Table 3. Condition factors and growth patterns of two Alestid species in the New Calabar River

\begin{tabular}{|c|c|c|c|c|c|}
\hline Species & \multicolumn{2}{|l|}{$\mathbf{K}$} & a & b & $\mathbf{r}^{2}$ \\
\hline $\begin{array}{l}\text { B. macrolepidotus } \\
\text { B. nurse }\end{array}$ & $\begin{array}{l}\text { Mean } \\
1.02 \pm 0.03 \\
1.08 \pm 0.02\end{array}$ & $\begin{array}{r}\text { Range } \\
0.61-1.56 \\
0.49-1.73 \\
\end{array}$ & $\begin{array}{l}-5.1712 \\
-5.9999\end{array}$ & $\begin{array}{l}3.2103 \\
3.5405 \\
\end{array}$ & $\begin{array}{l}0.8868 \\
0.8853 \\
\end{array}$ \\
\hline $\begin{array}{l}\text { The growth param } \\
\text { using the length freque } \\
\text { revealed the best fit for } \\
\text { per year while for } B . \text { ma } \\
\text { for } L_{\infty}=28.88 \mathrm{~cm} \text { an } \\
\text { The total mortality ( } Z \text { ) } \\
\text { length converted catch } \\
\text { while it was } 0.77 \text { for } B \text {. } \\
\text { mortality (M / year) as } \\
\text { was found to be } 1.05 \mathrm{f}\end{array}$ & $\begin{array}{l}\text { mated for } B . \text { nurse } \\
\text { ELEFAN I program } \\
46 \mathrm{~cm} \text { and } \mathrm{k}=0.52 \\
\text { tus, the best fit were } \\
\text { per year (Table } 4 \text { ). } \\
\text { se estimated by the } \\
\text { as } 1.88 \text { for } B . \text { nurse } \\
\text { idotus. The natural } \\
\text { s empirical formula } \\
\text { se while it was } 0.69\end{array}$ & \multicolumn{4}{|c|}{$\begin{array}{l}\text { The logistic regression of the probability of capture } \\
\text { routine values recorded for } B \text {. nurse was lower than } \\
\text { that of } B \text {. macrolepidotus (Table } 5 \text {, Fig } 4 \text { and } 5 \text { ). The } \\
\text { estimated } L_{50} \text { was } 14.49 \mathrm{~cm} \text { for } B \text {. nurse and } 17.64 \\
\mathrm{~cm} \text { for } B \text {. macrolepidotus. The } L_{25} \text { was calculated as }\end{array}$} \\
\hline
\end{tabular}


$12.88 \mathrm{~cm}$ and $15.13 \mathrm{~cm}$ while $\mathrm{L}_{75}$ was found to be $16.10 \mathrm{~cm}$ and $20.16 \mathrm{~cm}$ for both species, respectively. In this study, the reproductive load $\left(\mathrm{L}_{50} / \mathrm{L}_{\infty}\right)$ ratio was

Table 4. Population parameters of B. nurse and B. macrolepidotus

\begin{tabular}{lcc}
\hline Von Bertalanffy's Growth parameters & B. nurse & B. macrolepidotus \\
\hline Asymptotic length $\left(\mathrm{L}_{\infty}\right)$ & 24.46 & 28.88 \\
Growth coefficient $(\mathrm{k})$ & 0.52 & 0.22 \\
$t_{0}(\mathrm{yr})$ & 0.04 & 0.07 \\
Total mortality $(\mathrm{Z})$ & 0.83 & 0.77 \\
Fishing mortality $(\mathrm{F})$ & 0.22 & 0.08 \\
Natural mortality $(\mathrm{M})$ & 1.05 & 0.69 \\
Exploitation rate $(\mathrm{E})$ & 0.26 & 0.11 \\
\hline
\end{tabular}

Table 5. Length at capture of $B$. nurse and B. macrolepidotus

\begin{tabular}{ccc}
\hline Length at capture & B. nurse & B. macrolepidotus \\
\hline $\mathrm{L}_{25}$ & $12.88 \mathrm{~cm}$ & $15.13 \mathrm{~cm}$ \\
$\mathrm{~L}_{50}$ & $14.49 \mathrm{~cm}$ & $17.64 \mathrm{~cm}$ \\
$\mathrm{~L}_{75}$ & $16.10 \mathrm{~cm}$ & $20.16 \mathrm{~cm}$ \\
\hline
\end{tabular}

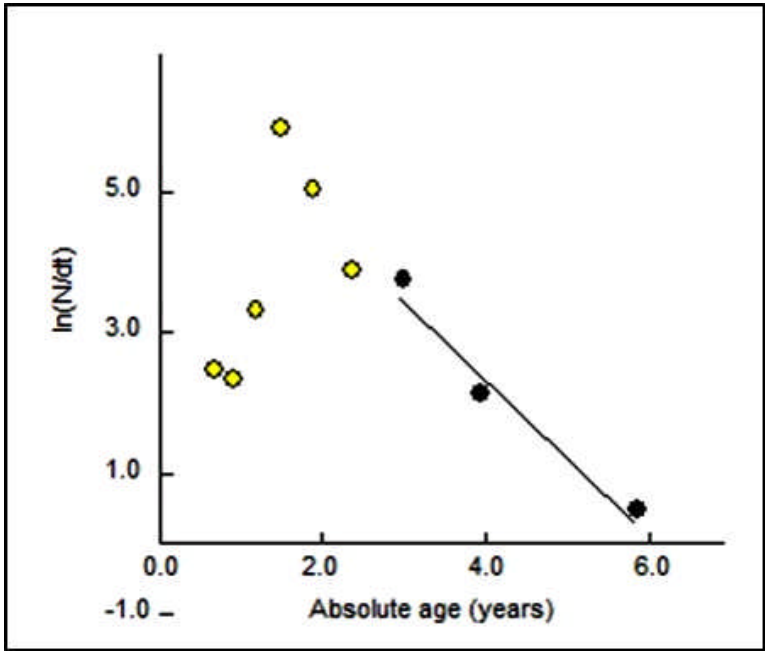

Figure 4. Length converted catch curves of B.nurse.

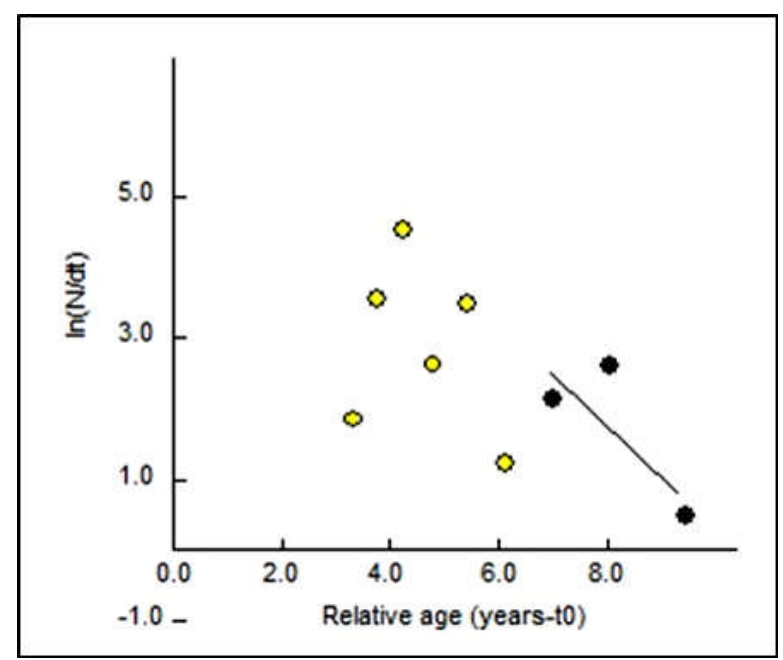

Figure 5. Length converted catch curves of B. macrolepidotus. 


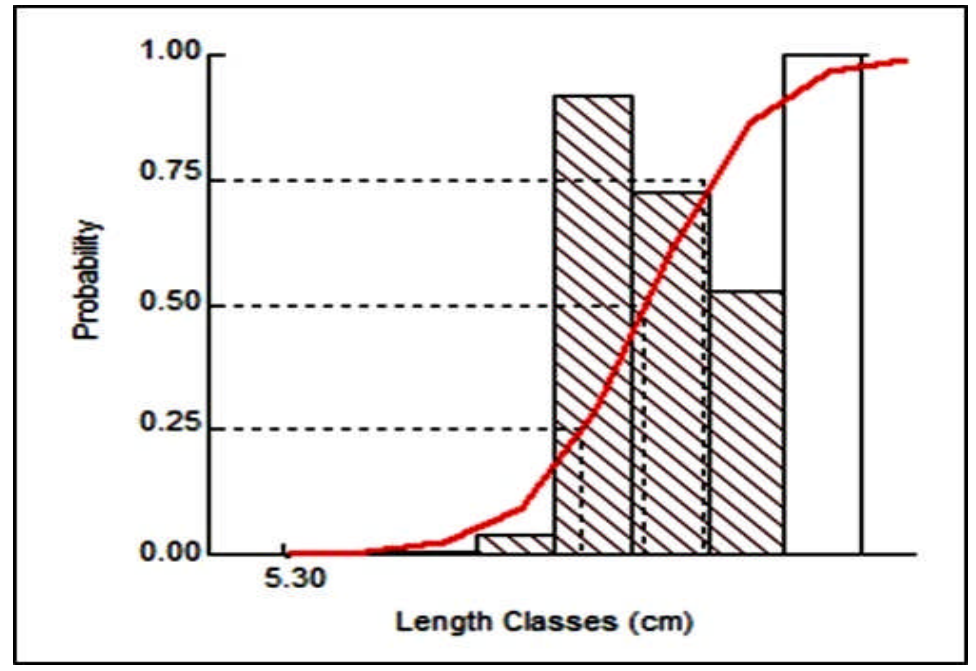

Figure 6. Length at first capture $\left(\mathrm{L}_{50}\right)$ for $B$. nurse.

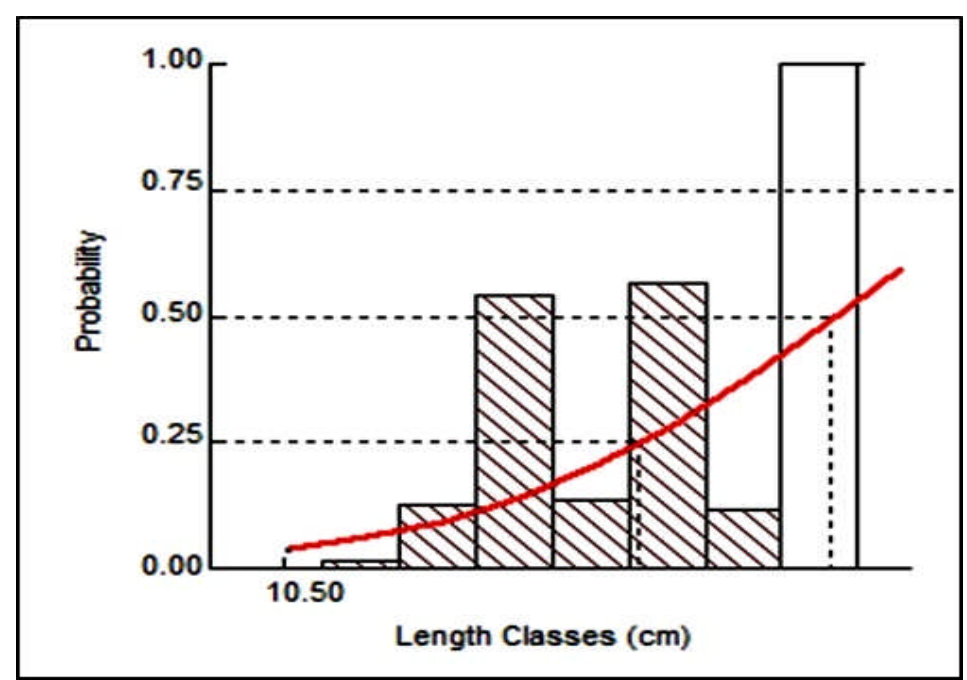

Figure 7. Length at first capture $\left(\mathrm{L}_{50}\right)$ for $B$. macrolepidotus.

The Beverton-Holt relative yield per recruit $\left(Y^{\prime} / R\right)$ and relative biomass per recruit $\left(B^{\prime} / R\right)$ were estimated using selective Ogive procedure of FiSAT. The analysis indicated that the exploitation rate, which maximises yield per recruit, produced values of $\mathrm{E}_{\max }=0.41,0.42$; $\mathrm{E}_{10}=0.36,0.36$ and $\mathrm{E}_{50}=0.28,0.29$ for B.nurse and B. macrolepidotus, respectively (Figs $7 \& 8$ ).

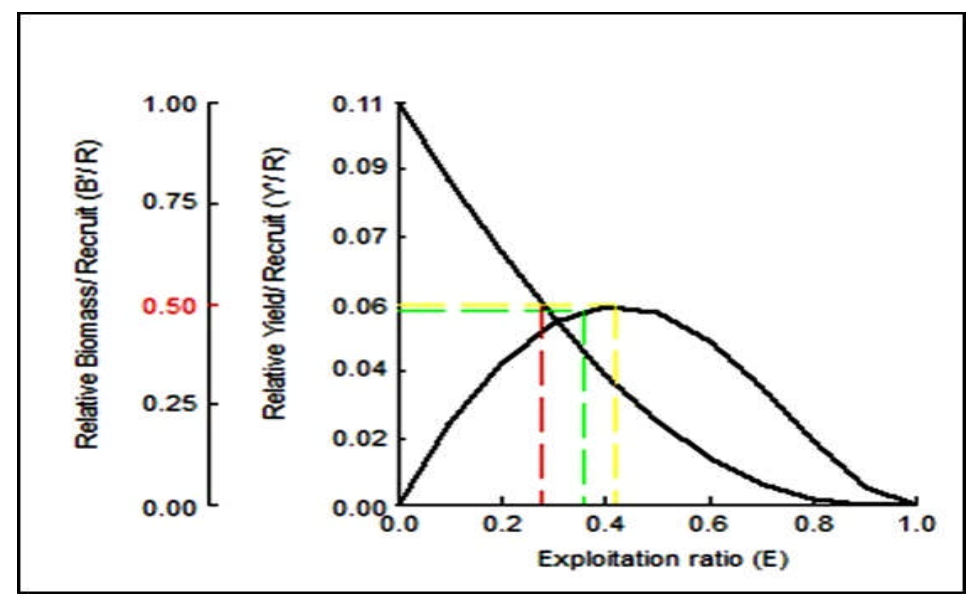

Figure 8. Stock status of $B$. nurse using Beverten and Holt's relative $Y / R$ analysis. 


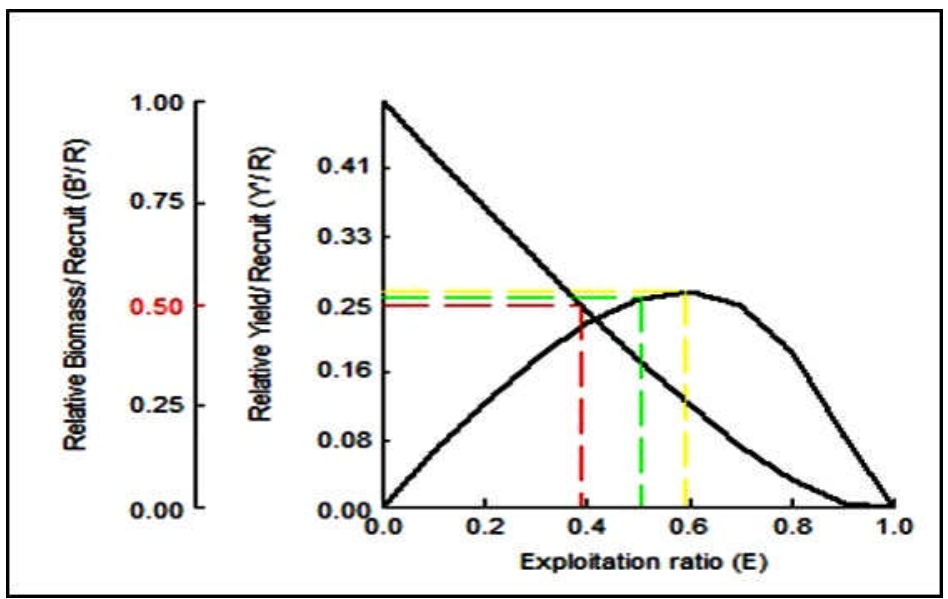

Figure 9. Stock status of $B$. macrolepidotus using Beverten and Holt's relative Y/R analysis.

\section{Discussion}

The calculated 'b' values of the LWRs, which were 3.2103 for B. macrolepidotus and 3.5405 for B. nurse, indicate positive allometric growth. The values fall within the acceptable range of 2.5 and 3.5 , which is typical for tropical fish stocks (Carlander, 1969; Froese, 2006). Gopakumar et al. (1991) opined that higher $b$ values imply a relatively productive environment. Positive allometric growth implies that the fish grows faster in weight than in length. A similar observation was also reported in $B$. nurse (3.0737) from the White Volta River in Ghana (Abobi \& Ekau, 2013). Echi \& Ezenwaji (2016) reported contrasting findings for $B$. macrolepidotus from the Anambra River, Nigeria with the males and females showed negative allometric growth (2.309 and 2.734, respectively); in the same vein, the other Alestid species reported in the study, such as Alestes baremoze, B. leuciscus, and Hydrocynus vitttatus, showed negative allometric growth for their respective male and female. The slight difference in the exponent 'b' values recorded could be associated with several factors, such as temperature, salinity, adequate food, seasonal changes, environmental conditions, sampling procedure, and sexual dimorphism.

The condition factor " $\mathrm{K}$ " of a fish can be defined as a measurement of the general health condition of the fish as calculated by the ratio of body weight to body length. This factor implies that whatever is able to affect the weight of fish will definitely affect the $\mathrm{K}$ values. Adesulu \& Sydenham (2007) reported that condition factor in fish is mainly affected by the amount of food in stomach and stage of egg development that will affect the weight of the body and then the weight of fish is a function of condition factor in fish. The "K" values of the two Alestid species in this study indicate that the population is in moderate growth condition as "K" values are slightly greater than 1 . This factor implies that the fishes thrive well in the habitat (Komolafe \& Arawomo, 2011). The condition factor for $B$. longipinnis was reported to range 1.94-2.80 in Ikomi \& Sikoki (2003).

The asymptotic length $\left(L_{\infty}\right)$ is the largest theoretical mean length that a fish could attain in its natural habitat, assuming the fish grows throughout its life (Abobi \& Ekau, 2013); while the growth curvature $(\mathrm{K})$ is the rate at which it grows towards this final size (Etim et al.,1999). In the present study, B. nurse had an asymptotic length $\left(L_{\infty}\right)$ of $24.46 \mathrm{~cm}$, growth curvature $(k)$ of 0.52 per year, and $t_{0}$ (per year) of 0.04 while $B$. macrolepidotus had $\mathrm{L}_{\infty}$ of $28.88 \mathrm{~cm}$, $\mathrm{k}$ of 0.22 per year, and $t_{0}$ (per year) of 0.07 (Table 4 ). These results indicate that both species are fast-growing.

The total mortality $(Z)$, natural mortality ( $M$ / year), fishing mortality $(F)$, and exploitation rate $(E)$ of $B$. nurse were found to be $1.88,1.05,0.83$ and 0.26 , respectively; while for $B$. macrolepidotus it was 0.77 , $0.69,0.08$ and 0.11 , respectively. Values of $Z, M$, and $F$ were higher for $B$. nurse than for $B$. macrolepidotus; however, since natural mortality $(M)$ exceeded fishing mortality $(F)$ for both species, the stock is not overexploited. The exploitation rate $(\mathrm{E})$ of $B$. nurse was 0.26 . Based on the assumption that a stock is optimally exploited when $\mathrm{F}=\mathrm{M}$ or $\mathrm{E}=0.5$ (Gulland, 1971). The results of the present study indicate that the current exploitation rate is close to the maximum level of 0.5 . The low value of $E$ in the two species in this finding suggests that levels of exploitation may be increased in order to reduce waste of stock through natural mortality; however, caution must be taken to avoid what can be called a skewed exploitation situation (Chukwu \& Deekae, 2010). Ahmad et al. (2018) reported lower values of $Z$ (1.31), M (1.0), F (0.31), and $E(0.24)$ for $B$. nurse from the Challawa Gorge dam, Kano. Higher values of the fore mentioned parameters were observed for $B$. nurse by Kwarfo- 
Apegyah et al. (2009) and Uneke \& Nwani (2013), respectively; $Z=2.54$ and $3.34 ; M=1.3$ and 1.80 ; $F=1.24$ and 1.54 ; and $E=0.49$ and 0.46 . However, the relatively lower values of $E$ in these studies indicate that the stocks were also not over-exploited.

The result of this study showed the estimated length at first capture $\left(L_{c}\right)$ of both Brycinus species to be 14.49 and $17.64 \mathrm{~cm}$ for $B$. nurse and $B$. macrolepidotus, respectively. The $L_{c}$ value recorded in this study falls within the range of the total length 7.30 to $23.00 \mathrm{~cm}$ for $B$. nurse and $11.50-27.00 \mathrm{~cm}$ for B. macrolepidotus. A lower value of $L_{c}$ (7.58) was recorded for $B$. nurse by Ahmad et al. (2018). Uneke and Nwani (2013) found the $L_{c}$ for $B$. nurse in Cross River to be 8.83 while Kwarfo-Apegyah (2008) found the $L_{c}$ for $B$. nurse in Bontanga Reservoir (Northern Region of Ghana) to be 10.94 .

The predicted $\mathrm{E}_{\max }$ of the Selective Ogive procedure for $B$. nurse and B. macrolepidotus $(0.41$ and 0.42 , respectively) were higher than their respective current exploitation rates $E(0.28$ and 0.29$)$ showing that both Brycinus species were not over-exploited. Uneke \& Nwani (2013) and Kwarfo-Apegyah et al. (2009) reported the $E$ of $B$. nurse to be 0.46 and 0.49 , respectively; both values are higher than the value of E estimated for the two Alestid species in this study. Values of $\mathrm{E}_{\max }, \mathrm{E}_{50}$, and $\mathrm{E}$ for B.nurse in the Challawa Gorge dam, Kano, were reported by Ahmad et al. (2018) as $0.65,0.2$, and 0.24 , respectively.

\section{CONCLUSIONS}

The present study provides some important baseline information on the growth and population of two commercially important fish species from the family Alestidae that will help in the development of efficient management strategies. The length-at-first capture $\left(L_{c}\right)$ of $B$. macrolepidotus estimated in this study showed that this species was caught at very small sizes concerning the use of small mesh size nets, such as $2.3 \mathrm{~mm}$ and $15 \mathrm{~mm}$. Natural mortality was greater than the fishing mortality for both $B$. nurse and $B$. macrolepidotus while exploitation rate $(E)$ was less than 0.5 for both species. Even though the difference between biological reference point and fishing mortality is small, it would be better for the well-being of fishery to introduce some fishery regulation measures.

\section{REFERENCES}

Abobi, S. M., \& Ekau, W. (2013). Growth, Mortalities and Exploitation Rates of Alestes baremoze(Joannis, 1835), Brycinus nurse
(Rüppell, 1832) and Schilbe intermedius (Rüppell 1832) from the lower reaches of the White Volta River (Yapei), Ghana. Journal of Agriculture and Biodiversity Research, 2(1), 1-10.

Abowei, J. F. N., \& Hart, A. I. (2009). Some morphometric parameters of ten finfish species from the lower Nun River, Niger Delta, Nigeria. Research Journal of Biological Sciences 4(3), 282288.

Adesulu, E. A., \& Sydenham, D. H. J. (2007). The freshwater and fisheries of Nigeria. Macmillan Nigeria Publishers, Lagos, Nigeria. 397 pp.

Ahmad, I. M., Yola, I.D., \& Suleiman, N. (2018). Mortality and Exploitation Rates of Challawa Gorge Dam Fishes, Kano State, Nigeria. Journal of Fisheries and Livestock Production, 6: 262, DOI: 10.4172/2332-2608.1000262.

Arroyave, J., \& Stiassny, M. L. J. (2011). Phylogenetic relationships and the temporal context for the diversification of African characins of the family Alestidae (Ostariophysi: Characiformes): Evidence from DNA sequence data. Molecular Phylogenetics and Evolution, 60, 385-397.

Beverton, R. J. H., \& Holt, S. J. (1966). Manual of methods for fish stock assessment. Part II. Tables of yield function. FAO Fisheries Technical Paper, 38(1), 67p.

Beverton, R.J.H. \& Holt, S.J. (1957) On the Dynamics of Exploited Fish Populations. Gt Britain Fish Invest. Ser. 2, Vol. 19, 1-533.

Boulenger, D. P. (2002). The biology of Brycinus species from Lekki Lagoon, Lagos State, Nigeria Journal of Science, 12, 73-84.

Carlander, K. D. (1969). Handbook of freshwater fishery biology. The lowa State University Press, Ames, IA. 1:752p.

Chukwu, K. O., \& Deekae, S. N. (2010). Growth, mortality, and recruitment of Periopthalmus barbarus (Linneaus, 1766) in New Calabar River, Nigeria. Agriculture and Biology Journal of North America, 2(7), 1066-1068.

Echi, P. C. \& Ezenwaji, H. M. G. (2016). Length-Weight relationships and food and feeding habits of some Characids (Osteichthyes: Characidae) from Anambra River basin, Nigeria. Animal Research International, 13(1), 2316-2320. 
Etim, L., Lebo, P. E., \& King, R. P. (1999). The dynamics of an exploited population of a siluroid catfish (Schilbe intermidius, Reupell 1832) in the Cross River, Nigerian. Fisheries Research, 40, 295-307.

Froese, R., \& Pauly, D. (eds.) (2017). List of Freshwater Fishes reported from Nigeria. FishBase. World Wide Web electronic publication. Retrieved from www.fishbase.org. Accessed 1 August 2018.

Froese, R., \& Pauly, D. (Editors) (2016). FishBase. World Wide Web electronic publication. [Online]. www.fishbase.org. Accessed 14 September, 2018.

Froese, R. (2006). Cube law, condition factor, and length-weight relationships: History, meta-analysis, and recommendations. Journal of Applied Ichthyology, 22, 241-253.

Gayanilo, F. C., Sparre, P., \& Pauly, D. (2005). FAOICLARM Stock Assessment Tools II (FiSAT II).User's guide. FAO Computerized Information Series (Fisheries). No. 8, revised version, FAO, Rome, $168 \mathrm{pp}$.

Gopakumar, G., Pillai, P. P., \& Koya, K. P. (1991). Population characteristics of tuna live baits in Lakshadweep. Journal of Marine Biological Association India, 33(1-2), 255-277.

Gulland, J. A. (1971). The Fish Resources of the Ocean. 1st Edn. Fishing News Books, London, pp. 255.

Hoggarth, D. D., Abeyasekera, S., Arthur, R., Beddington, J. R., Burn, R. W., Halls, A. S., Kirkwood, G. P., McAllister, M., Medley, P., Mees, C. C., Pilling, G. M., Wakeford, R. \& Welcomme, R. L. (2006). Stock assessment and fishery management - A framework guide to the FMSP stock assessment tools", FAO Fisheries Technical Paper No. 487, Rome, Italy, 261 pp. 17

Hossain, M. Y., Ohtomi, J., \& Ahmed, Z. F. (2009). Morphometric, meristic characteristic and conservation of the threatened fish, Puntius sarana (Hamilton 1822) (Cyprinidae) in the Ganges River, northwestern Bangladesh. Turkish Journal Fisheries and Aquatic Sciences, 9, 223-225.

Ikomi, R. B., \& Sikoki, F. D. (2003). Studies on the ecology of the African longfin tetra, Brycinus longipinnis (Gunther, 1864) in the Jamieson River (Niger Delta, Nigeria) Acta Ichthyologica. Piscatoria, 33(1), 17-36.
Kohler, N., Casey, J. \& Turner, P. (1995). Lengthweight Relationship for 13 Species of Sharks from Western North Atlantic. Fisheries Bulletin, 93, 412414.

Komolafe, O. O., \& Arawomo, G. A. O. (2011). Observations in the composition, physiological condition, and fisheries in Erinle Lake, Osun state, Nigeria. West African Journal of Applied Ecology, 18, 71-78.

Kwarfo-Apegyah, K. (2008). Ecology and stock assessment of major fish species of Bontanga reservoir for sustainable management. (Ph.D. Thesis.) Department of Oceanography and Fisheries, University of Ghana, Legon, 216 pp.

Kwarfo-Apegyah, K., Ofori-Danson, P. K., \& Nunoo, F. K. E. (2009). Exploitation rates and management implications for the fisheries of Bontanga Reservoir in the Northern region of Ghana. West African Journal of Applied Ecology, 14 , 1-7. http://dx.doi.org/10.4314/ wajae.v14i1.44710

National Bureau of Statistics (NBS) (2017). Nigerian's fish production 2010-2015. Data is supplied, verified and validated by the National Bureau of Statistics, Nigeria (NBS). https:// www.nigerianstat.gov.ng/elibrary. Accessed on 17 June 2018

Olopade, O. A., Dienye, H. E., \& Eyekpegha, A. (2018). Length frequency distribution, length-weight relationship and condition factor of cichlid fishes (Teleostei: Cichlidae) from the New Calabar River, Nigeria. Iranian Journal of Ichthyology 5(1), 7480.

Patterson, K. (1992). Fisheries for small pelagic species: an empirical approach to management targets. Reviews in Fish Biology and Fisheries, 2, 321-338. https://doi.org/10.1007/BF00043521

Pauly, D. \& Soriano, M. L. (1986). Some practical extensions to Beverton and Holt's relative yieldper-recruit mode. In: Maclean, J.L. Dizon, L.B., Hosillos. L.V. (Eds.)The First Asian Fisheries Forum, Asian Fisheries Society, Manila, Philippines, pp. 491-496.

Pauly, D. (1984). Fish population dynamics in tropical waters: a manual for use with programmable calculators. ICLARM Stud. Rev., (8), 325. 
Pauly, D. (1980). On the interrelationships between natural mortality, growth performance and mean environmental temperature in 175 fish stock. Journal of Marine Sciences, 39(2), 175-192.

Paugy, D., \& Schaefer, S. A. (2007). Alestidae. p. 347-411. In: Stiassny, M.L.J., Teugels, G.G. and C.D. Hopkins (Editors), Poissons d'eaux douces et saumâtres de basse Guinée, ouest de l'Afrique centrale/The fresh and brackish water fishes of Lower Guinea, west-central Africa. Vol. 1. Coll. Faune et Flore tropicales 42. Institut de recherche pour le développement, Paris, France, Muséum nationale d'histoire naturelle, Paris, France and Musée royale de l'Afrique centrale, Tervuren, Belgique. $800 \mathrm{p}$.

Paugy, D. (2003). Alestidae. p. 236-282. In: Paugy, D., Lévêque, C. and Teugels, G. G. (Editors), The fresh and brackish water fishes of West Africa Volume 1. Coll. faune et flore tropicales 40 . Institut de recherche de développement, Paris, France, Muséum national d'histoire naturelle, Paris, France and Musée royal de l'Afrique Central, Tervuren, Belgium, $457 \mathrm{pp}$.

Reed, W. J., Buchard, A. J., Hopson, J., Jennes, J., \& Yaro, I. (1967). Fish and fisheries of Northern Nigeria. Ministry of Agriculture, Northern Nigeria. $226 \mathrm{pp}$.
Ricker, W. E. (1975). Computations and interpretation of biological statistics of fish populations. Fisheries Research Board Canada Bulletin, 191: 382.

Ricker, W. E. (1973). Linear regressions in ûshery research. Journal Fisheries Research Board Can. $30,409-434$.

Ricker, W. E. (1968). Methods for Assessment of Fish Production in Freshwaters. IBP Handbook No. 3. Blackwell Scientific Publications, Oxford and Edinburgh, UK. 313 pp.

Saliu, J. K., \& Fagade, S. O. (2004). The Structural and Functional Morphology of the Hard Parts of Brycinus nurse (Pisces: Cypriniformes, Characidae), From Asa Reservoir, llorin, Nigeria. Turkish Journal of Fisheries and Aquatic Sciences, 4:23-31

Uneke, B. I., \& Nwani, C. D. (2013). Stock assessment of Brycinus nurse (Characiformes: Alestidae) in a tropical flood river basin. Continental Journal of Fisheries and Aquatic Science, 7(3), 22-33.

Wang, Y. \& Liu, L. (2006). Estimation of natural mortality using statistical analysis of fisheries catch-at age data. Fisheries Resources, 78, 342351. 